the preparation and planning of the Congress, will be Prof. G. E. Fogg, Department of Botany, Westfield College, Hampstead, London, N.W.3, and Dr. A. J. Brook, Department of Botany, University of Edinburgh, at the Royal Botanic Garden, Edinburgh 3.

\section{The Night Sky in June}

New moon occurs on June 13d. 05h. 17m. U.T. and full moon on June $28 \mathrm{~d} .12 \mathrm{~h} .38 \mathrm{~m}$. The following conjunctions with the Moon take place: June 2d. 18h., Saturn $3^{\circ}$ S.; June 3d. 06h., Jupiter $3^{\circ}$ S.; June 9d. 09h., Venus $2^{\circ}$ N.; June 18d. 10h., Mars $2^{\circ}$ N.; June 18d. 20h., Regulus 0.5 N.; June 30d. $00 \mathrm{~h}$. Saturn $3^{\circ} \mathrm{S}$; June 30d. 12h., Jupiter $3^{\circ} \mathrm{S}$. In addition to these conjunctions with the Moon, Mars is in conjunction with Regulus on June 27d. $08 \mathrm{~h} .$, Mars being $0.7^{\circ} \mathrm{N}$. Mercury is an evening star, visible during the first fow days of the month low in the west after sunset; later in the month it is too close to the Sun for observation. Venus is a morning star, rising at $2 \mathrm{~h} .15 \mathrm{~m}$., $1 \mathrm{~h}$. $50 \mathrm{~m}$. and $1 \mathrm{~h} .25 \mathrm{~m}$., on June 1, 15 and 30, respectively. Its stellar magnitude on June 15 is $-4 \cdot 0$; the visible portion of the apparent disk increases from 0.379 to 0.555 during the month, and its distance from the Earth increases from 51 to 73 million miles. Mars is an evening star, but conditions for observation are becoming less favourable. It sets at $23 \mathrm{~h}$. $30 \mathrm{~m}$. on June 15 . Jupiter rises at $23 \mathrm{~h} .40 \mathrm{~m} ., 22 \mathrm{~h} .45 \mathrm{~m}$. and $21 \mathrm{~h} .40 \mathrm{~m}$. on June 1, 15 and 30, respectively. It is in Capricornus; its stellar magnitude on June 15 is -2.2 and its distance from the Earth on that date is 400 million miles. Saturn rises at $23 \mathrm{~h}$. $20 \mathrm{~m} ., 22 \mathrm{~h}$. $20 \mathrm{~m}$. and $21 \mathrm{~h} .15 \mathrm{~m}$. at the beginning, middle and end of the month, respectively. It is near the border of Sagittarius and Capricornus; its stellar magnitude on June 15 is +0.5 and its distance from the Earth is 850 million miles. There is one occultation of a star brighter than magnitude 6 visible at Greenwich: June 3 d. Ih. $42 \cdot 2 \mathrm{~m}$, $\rho$ Cap. reappearance. The summer solstice occurs on June 21d. 16h.

\section{Announcements}

Mr. M. J. LighthiLL, director of the Royal Aircraft Establishment, Farnborough, has been awarded the Hopkins Prize of the Cambridge Philosophical Society for his contributions to fluid mechanies. The Prize has been awarded every three years since 1867 for work in mathematical-physical or related fields; the present award relates to the period 1957-60 and is of the value of $£ 200$.

Mr. Charles A. Marshall, editor of British $\mathrm{Com}^{-}$ munications and Electronics, has been appointed honorary secretary of the Television Society in succession to Mr. Geoffrey Parr, who has been elected to an honorary life fellowship of the Society in recognition of his services during the past fifteen years. Mr. Parr will continue to edit the Society's Journal.

A summer school in quantum ehemistry is being organized by Prof. C. A. Coulson and the Delegacy for Extra-mural Studies at St. Antony's College, University of Oxford, during September 9-23. Further information can be obtained from the Secretary, Extra-mural Delegacy, Rawley House, Wellington Square, Oxford.

THE Institution of Engineering Inspection and the Society of Non-Destructive Examination are jointly organizing a conference at Oxford during September
5-8. Further information can be obtained from the Oxford Conference Secretariat, Institution of Engineering Inspection, 616 Grand Buildings, Trafalgar Square, London, W.C.2.

A Conference is to be organized jointly by the University of Southampton and the Timber Development Association on "Timber Engineering", at the University of Southampton, during September 18-23. Further information can be obtained from Dr. H. G. Allen, Department of Civil Engineering, University of Southampton.

A symposium on North Atlantic biota and their history is being arranged under the sponsorship of the NATO Advanced Study Institutes Programme and will be held in Reykjavik during the first two weeks of August. Further information can be obtained from Dr. Áskell Löve, Institut Botanique de l'Université de Montréal, 4101 est, rue Sherbrooke, Montreal.

The Netherlands University Foundation for Inter national Co-operation is organizing a summer school in science, which will be devoted to "Fundamental Problems in Statistical Mechanics", at Breukelen, The Netherlands, during August 1-16. Further information can be obtained from the Registrar, Netherlands University Foundation for International Co-operation, 27 Molenstraat, The Hague, The Netherlands.

A symposium on "Photomultiplier Tube Applications" is to be held at E.M.I. House, Manchester Square, London, W.1, during September 13-15. The symposium is being organized for the exchange of information on the application of photomultiplier tubes in a wide variety of scientific and industrial fields by E.M.I. Electronics, Ltd. A small nominal fee will be charged. Further information can be obtained from Mr. B. Johnson, Press Officer, E.M.I. Electronics, Ltd., Hayes, Middlesex.

A NEW series of publications, the Annual Review of Astronomy and Astrophysics, is being arranged by Annual Reviews, Inc., Palo Alto, California. The first volume will appear in the autumn of 1963 , under the editorship of Dr. Leo Goldberg, Higgins professor of astronomy, Harvard University.

Transcatrons into English of the Russian optics and spectroscopy journal, Optika $i$ Spektroskopiya, have been arranged by the Optical Society of America. Special terms have been arranged for societies wishing to join the translation scheme and non-members and libraries. Further information can be obtained from the Assistant Secretary, OSA, 1155 16th Street, N.W., Washington 6, D.C.

Vor. 4, Part 5, of Scientific Institutions and Scientists in Latin America, issued by the United Nations Educational, Scientific and Cultural Organization, Montevideo, contains information received during the printing of the three former volumes, to which it is an appendix ( $\mathrm{Pp} . \mathrm{i}+707-767$. Montevideo : Unesco; Centro de Co-operacion cientifica para America Latina, 1960).

Hilger AND Watts, Ltd., announce that Wray (Optical Works), Ltd., have come into association with them. Mr. A. W. Smith, a former president of the Scientific Instrument Manufacturers' Association, and chairman of its Education Committee, is continuing as managing director of Wray (Optical Works), Ltd. 